\title{
Widespread mixotrophy in reef-inhabiting soft corals: the influence of depth, and colony expansion and contraction on photosynthesis
}

\author{
K. E. Fabricius ${ }^{1,2, *}$, D. W. Klumpp ${ }^{1}$ \\ ${ }^{1}$ Australian Institute of Marine Science, PMB 3, Townsville, Queensland 4810, Australia \\ ${ }^{2}$ Centre of Tropical Marine Ecology, Klagenfurter Str./GEO, D-28359 Bremen, Germany
}

\begin{abstract}
Primary production, respiration, and bathymetric distribution were investigated in the 10 most common zooxanthellate soft coral genera of mid-shelf reefs of the central Great Barrier Reef, Australia. Oxygen flux of corals, collected from 5 to $20 \mathrm{~m}$ depth, was measured at $6 \mathrm{~m}$ water depth over $24 \mathrm{~h}$ using data-logging respirometers. In most taxa, photosynthetic carbon acquisition was lower than respiratory carbon loss under irradiance conditions of cloudless summer days at $20 \mathrm{~m}$ depth [mean rate of net photosynthesis $P_{\mathrm{n}}$ for all taxa: $-1.0 \pm 0.5$ (SE) $\mathrm{mg} \mathrm{C}^{-1}$ ash-free dry weight (AFDW) $\mathrm{d}^{-1}$ ), and only slightly higher than respiration at $5 \mathrm{~m}$ depth (mean $P_{\mathrm{n}}=1.2 \pm 0.7 \mathrm{mg} \mathrm{C} \mathrm{g}^{-1}$ AFDW d ${ }^{-1}$ ). Hence, most if not all zooxanthellate taxa were also dependent upon heterotrophic nutrition to cover their carbon demand. Colony contraction significantly reduced photosynthetic productivity in soft coral taxa possessing large polyps. Levels of irradiance required to achieve photosynthetic compensation $\left(I_{c}\right)$ and saturation $\left(I_{k}\right)$ were higher in contracted compared with expanded colonies. The moderate dependence of soft corals on phototrophy was reflected in their bathymetric distribution at Davies Reef. Highest soft coral densities were found at $20 \mathrm{~m}$ depth where maximum irradiance was attenuated to about $180 \mu \mathrm{E}$ $\mathrm{m}^{-2} \mathrm{~s}^{-1}$, equivalent to $16 \%$ of surface irradiance. At the deeper limits to the distribution of the zooxanthellate taxa, irradiance was sufficient for photosynthesis to compensate respiration for 3 to $6 \mathrm{~h} \mathrm{~d}^{-1}$, but was insufficient to saturate photosynthesis.
\end{abstract}

KEY WORDS: Octocorallia - Alcyonaceae Photosynthesis - Respiration - Nutrition - Bathymetric distribution - Colony contraction C Coral reefs Great Barrier Reef

\section{INTRODUCTION}

Soft corals (Octocorallia: Alcyonaceae) represent the most abundant and species-rich order of octocorals on Indo-Pacific coral reefs. They are also the most important component of non-reef-building benthos on the central Great Barrier Reef, Australia, and in some areas their density can equal or exceed that of stony corals (Dinesen 1983). In spite of their numerical importance, the biology of soft corals has received little attention. This is partly because laboratory and field experiments are complicated by difficulties in identifying live colonies, and their high sensitivity to handling. Thus, soft coral nutrition is poorly understood.

•E-mail: k.fabricius@aims.gov.au
Most shallow-water reef inhabiting soft corals possess zooxanthellae, hence it is expected that some proportion of the host's carbon requirements will be met by photosynthates transferred from the endosymbiotic algae. Contrary to this potential for phototrophy among such soft corals, their abundance on mid-and outer-shelf reefs of the Great Barrier Reef is usually greatest around $20 \mathrm{~m}$ depth (see below), where irradiance is strongly attenuated. This suggests either that these corals are photosynthetically efficient at low irradiance levels, or that they are only moderately dependent on primary production, gaining the balance of their energy needs through heterotrophy. Suspension feeding on phytoplankton is the predominant mode of heterotrophic nutrition in some asymbiotic soft corals (Fabricius et al. 1995), and this may be supplemented by the uptake of dissolved organic matter (Schlichter 
1982). Octocorals are equipped with simple nematocysts (Mariscal \& Bigger 1977), which may be either ineffective or incapable of paralyzing zooplankton. And indeed, the predatory abilities of soft corals are poor compared with hard corals (Farrant et al. 1987. Sorokin 1991, Fabricius et al. in press).

Early in the study it was evident that coenenchyme (body) and polyp expansion and contraction had a major influence on photosynthetic productivity. Thus, the state of contraction/expansion of specimens was monitored during each metabolic measurement. In the field, octocorals are commonly found contracted during the day, for yet unknown reasons. Some suggested functions of contraction in anthozoans are nutrient and energy conservation (e.g. by reduction of nutrient loss through the epidermis), and predator avoidance (Sebens \& DeRiemer 1977, Shick et al. 1979). However, there are several ways in which contraction could reduce the gain of energy by soft corals, and thus counteract any benefits of energy conservation. Phototrophy may decrease during contraction, since the greatest proportion of zooxanthellae are located within the polyps (some are also embedded into the upper tissue layers of the coenenchyme), and these may be shaded when polyps retract. Moreover, contracted polyps are unlikely to capture food particles, and their ability to absorb dissolved organic matter may be reduced as a result of lowered surface area and decreased water turbulence around the colony.

The main goal of this study was to assess the contribution of phototrophy to the carbon requirements of the most common soft coral taxa inhabiting the upper $20 \mathrm{~m}$ on the central Great Barrier Reef. The effect of depth and degree of colony contraction on this process was also examined. For this purpose, the relationships between irradiance and oxygen flux rates of 10 zooxanthellate soft coral taxa collected from 5, 10 and $20 \mathrm{~m}$ depth were measured using in situ respirometry at a depth of $6 \mathrm{~m}$ on the reef. These measurements and data on the variation in irradiance with depth were used to model gross and net photosynthetic productivity in shallow waters $(5 \mathrm{~m})$ and at the depth of greatest soft coral abundance $(20 \mathrm{~m})$. The natural depth range of the same taxa was assessed at Davies Reef, and their lower depth limits and phototrophic characteristics compared.

\section{METHODS}

Study specimens and field sites. The taxa investigated represent the most abundant soft coral genera in mid-and outer-shelf reefs of the central Great Barrier Reef (Fabricius in press), and included all common morphological polyp types and colony growth forms (Table 1). We determined the photosynthetic and respiratory rates of 10 zooxanthellate genera, and the respiratory rates of 2 azooxanthellate genera. Samples of Xenia, Sinularia, Sarcophyton and Lobophytum contained several species, but the other genera investigated were monospecific. Either one specimen in a group of daughter colonies, or a small sample from each of the investigated colonies was collected for taxonomic identification. These samples are held at the Northern Territory Museum, Darwin, N.T., Australia.

Respirometric measurements. Respirometric measurements were carried out in situ at a depth of $6 \mathrm{~m}$ on mid-shelf reefs (mostly Davies Reef, and a few reefs close by) of the central Great Barrier Reef (Lat. 18-19 $\mathrm{S}$ ) during August and December 1991, November 1992 and March 1993. Coral colonies were collected from 5, 10 and $20 \mathrm{~m}$ depth at least $6 \mathrm{~h}$ prior to the start of the measurements. Colonies were detached with their substratum, freed of epibionts, thoroughly cleaned with a nylon brush, and mounted on a short PVC pipe stand. At no time were the samples exposed to air. Only colonies which appeared to have fully recovered from handling were used in the respirometry incubations.

Table 1. Characteristics of investigated soft coral taxa: presence of zooxanthellae, colony growth form, estimated polyp diameter in expanded state, and polyp contractibility into the coenenchyme

\begin{tabular}{|c|c|c|c|c|}
\hline Taxon & $\begin{array}{l}\text { Presence } \\
\text { of zoox. }\end{array}$ & $\begin{array}{c}\text { Colony } \\
\text { growth form }\end{array}$ & $\begin{array}{l}\text { Polyp dia- } \\
\text { meter (mm) }\end{array}$ & $\begin{array}{c}\text { Contractile } \\
\text { polyps }\end{array}$ \\
\hline \multicolumn{5}{|l|}{ Family Xeniidae } \\
\hline Efflatounaria sp. & + & Lobate & $4-8$ & + \\
\hline Xenia spp. & + & Capitate & $4-10^{a}$ & - \\
\hline \multicolumn{5}{|l|}{ Family Nephtheidae } \\
\hline Dendronephthya $2 \mathrm{spp}$. & - & Arborescent & 3 & - \\
\hline Scleronephthyd sp. & - & Arborescent & $3-4$ & - \\
\hline Nephthea sp. & + & Arborescent & $2-3$ & - \\
\hline Paralemnalia digutiformis & + & Digitate & 2 & + \\
\hline Paralemnalia clavata & + & Digitate & $2-3$ & + \\
\hline Capnella lacertiliensis & + & Lobate & $1-2$ & - \\
\hline \multicolumn{5}{|l|}{ Family Alcyoniidae } \\
\hline Sarcophyton spp. & + & Mushroom shaped & $4-8^{d}$ & + \\
\hline Sinularia $7 \mathrm{spp}$ & + & Encrusting with lobes & $3-6$ & + \\
\hline Lobophytum spp. & + & Encrustıng with lobes & $5 \quad 4-8^{a}$ & + \\
\hline \multicolumn{5}{|l|}{ Family Asterospiculariidae } \\
\hline Asterospicularia sp. & + & Lobate & $3-4$ & + \\
\hline \multicolumn{5}{|l|}{ Family Briareidae } \\
\hline Briareum stechei & + & Thin-encrusting & $4-5^{2}$ & + \\
\hline \multicolumn{5}{|c|}{${ }^{2}$ Polyps with long flexıble stems } \\
\hline
\end{tabular}


Two data-logging underwater respirometers, each with 4 replicate perspex chambers, were used to record simultaneous variations in chamber oxygen concentration, irradiance and temperature over $24 \mathrm{~h}$ (for technical details see Klumpp et al. 1987). The volume of chambers (2.4 l) was 50 to 120 times the volume of the soft coral specimens. During incubation, the water in the chambers was continuously stirred by propellers. Changes in oxygen concentrations in the chambers were recorded at $1 \mathrm{~min}$ intervals for $15 \mathrm{~min}$, followed by an automatic and complete 1 min flushing of the chamber water, prior to the commencement of the next 15 min series of readings. Oxygen levels deviated less than $20 \%$ from that of the ambient sea water. Pilot studies had shown that respiration rates were stable during such $15 \mathrm{~min}$ incubations, whereas rates started to fluctuate considerably after 1.5 to $2 \mathrm{~h}$.

The degree of expansion or contraction of each coral was recorded visually at $3 \mathrm{~h}$ intervals during the day, and once or twice at night for every respirometry run. After $24 \mathrm{~h}$, the respirometers and specimens were retrieved. The volume of contracted colonies was measured by displacement and used to estimate the volume of water in the respirometer chamber. The colonies in a well contracted state were stored frozen until their dry weight (dried to constant weight at $58^{\circ} \mathrm{C}$ ) and ash-free dry weight (AFDW, ashed for $4 \mathrm{~h}$ at $200^{\circ} \mathrm{C}$ and then $460^{\circ} \mathrm{C}$ for another $4 \mathrm{~h}$ ) were determined. Very little water was retained in the gastrovascular spaces of these wellcontracted colonies to bias the weight measurements.

Bathymetric distribution. The bathymetric distribution of the soft coral taxa used in respirometry was studied at Davies Reef. Belt transects (63 transects of $25 \times 0.5 \mathrm{~m}$ ) were surveyed along the windward and leeward slopes of this lagoonal reef. Transects were run perpendicular to the slope at $5 \mathrm{~m}$ depth intervals from $5 \mathrm{~m}$ depth downward to the bottom (deepest transects: $30 \mathrm{~m}$ on the windward side, $25 \mathrm{~m}$ on the leeward side and $20 \mathrm{~m}$ on the northern and southern flank). The mean diameters of all encountered soft corals were recorded along the transects. Asterospicularia sp. was not encountered on Davies Reef, therefore no data on the bathymetric distribution of this taxon are available. The transmission of photosynthetically active radiation (PAR) was measured (Lambda Li-Cor $2 \pi$ underwater quantum sensor) at intervals between 5 and $30 \mathrm{~m}$ depth on Davies Reef, during midday on 3 consecutive cloudless days (November 1992) after a period of calm conditions (waves $<0.3 \mathrm{~m}$ ).

Data analysis. Data on metabolic rates of colonies in contracted (CO) and expanded (EX) states were analyzed separately. An intermediate category (IN) was applied to samples in which the state of the specimens changed more than twice within $24 \mathrm{~h}$, or which were neither fully expanded nor contracted for considerable periods of time. Exponential and hyperbolic functions were fitted to the photosynthesis-irradiance $(P-I)$ data (Chalker et al. 1983, Nelson \& Siegrist 1987). The exponential function, $P_{\mathrm{g}}=P_{\mathrm{m}}\left(1-\mathrm{e}^{-I / t_{k}}\right)$, where $P_{\mathrm{m}}$ is the maximum net oxygen production rate, $I$ is irradiance, and $I_{k}$ is the $50 \%$ saturation irradiance $\left(I_{\text {sat }}\right)$, is presented here as it gave the best fit to our data $\left(\mathrm{r}^{2}=0.975\right.$ to 0.999$)$. Oxygen flux rates were converted to carbon equivalents assuming $\mathrm{PQ}$ (production quotient) = $1.1 \mathrm{O}_{2} / \mathrm{CO}_{2}$ and $\mathrm{RQ}$ (respiratory quotient) $=0.8 \mathrm{CO}_{2} / \mathrm{O}_{2}$ (Muscatine et al. 1981, Hatcher 1989), and $1 \mathrm{mg} \mathrm{O} \mathrm{O}_{2}=$ $0.375 \mathrm{mg} \mathrm{C}$. The average oxygen consumption at night (dark respiration, $R$ ) was used as the overall respiration rate. Gross production $\left(P_{\mathrm{g}}\right)$ and net production $\left(P_{\mathrm{n}}=\right.$ $P_{\mathrm{g}}-R$ ) at 5 and $20 \mathrm{~m}$ depth in summer were calculated by solving for $P$ in the relevant $P-I$ function over the $24 \mathrm{~h}$ PAR cycles. These PAR cycles were measured at $5 \mathrm{~m}$ depth on cloudless days in November at Davies Reef, and extrapolated to $20 \mathrm{~m}$ depth using the measurements of irradiance attenuation with depth (see above). Calculations of photosynthetic saturation periods were based on the approximation that $I_{\text {sat }}$ is twice $I_{k}$ (Chalker et al. 1983). $P_{g} / R_{24} \mathrm{~h}$ was defined as the ratio of the daily integrated gross oxygen production by the zooxanthellae $\left(P_{g}\right)$ to the $24 \mathrm{~h}$ dark respiration of both coral and algae $\left(R_{24} \mathrm{n}\right)$ according to Muscatine et al. (1981). Work on hard corals has suggested that $R$ during periods of active photosynthesis is higher than $R$ during darkness (Muller-Parker 1984, Edmunds \& Davies 1988). In a pilot study we completely shaded 4 Capnella lacertiliensis colonies at noon after exposure to high irradiance. In all colonies, the resultant oxygen consumption rates were initially 20 to $30 \%$ higher than the night respiration values, and decreased to night levels after 60 to $90 \mathrm{~min}$. Thus, our estimates of both $R_{24} \mathrm{~h}$ and $P_{\mathrm{g}}$ may be underestimated since they are based on night respiration. $P_{\mathrm{n}}$ would not be affected by this.

All statistical analyses were done using the SAS package. The Wilcoxon paired-sample test was used to compare metabolic values between contracted and expanded states within individuals. Mann-Whitney nonparametric between-groups comparison was used to test for differences in metabolic parameters between samples from different depths.

\section{RESULTS}

\section{Photosynthesis, respiration and the influence of contraction and expansion on primary production}

Rates of dark respiration and maximum photosynthesis, P-I parameters, and photosynthetic efficiency, derived from 201 measurements on 150 colonies, are summarized in Table 2 . Dark respiration rates $(R)$ were 
Table 2. Rates of photosynthesis and respiration in 13 common soft coral genera from the Great Barrier Reef. Dendronephthya spp. and Scleronephthya sp. are azooxanthellatec taxa, all others contain zooxanthellae. EX: expanded; CO: contracted; IN intermediate state, or state changed several times during measurements. $\mathrm{D}$ : depth of collection; n: number of measurement series; $R$ : dark respiration; $P_{\mathrm{m}}$ : maximum photosynthetic rate; $I_{c}$ : photosynthetic compensation irradiance; $I_{k}: 50 \%$ saturation irradiance; $\alpha$ : photosynthetic efficiency; AFDW: ash-free dry weight; SE: standard error

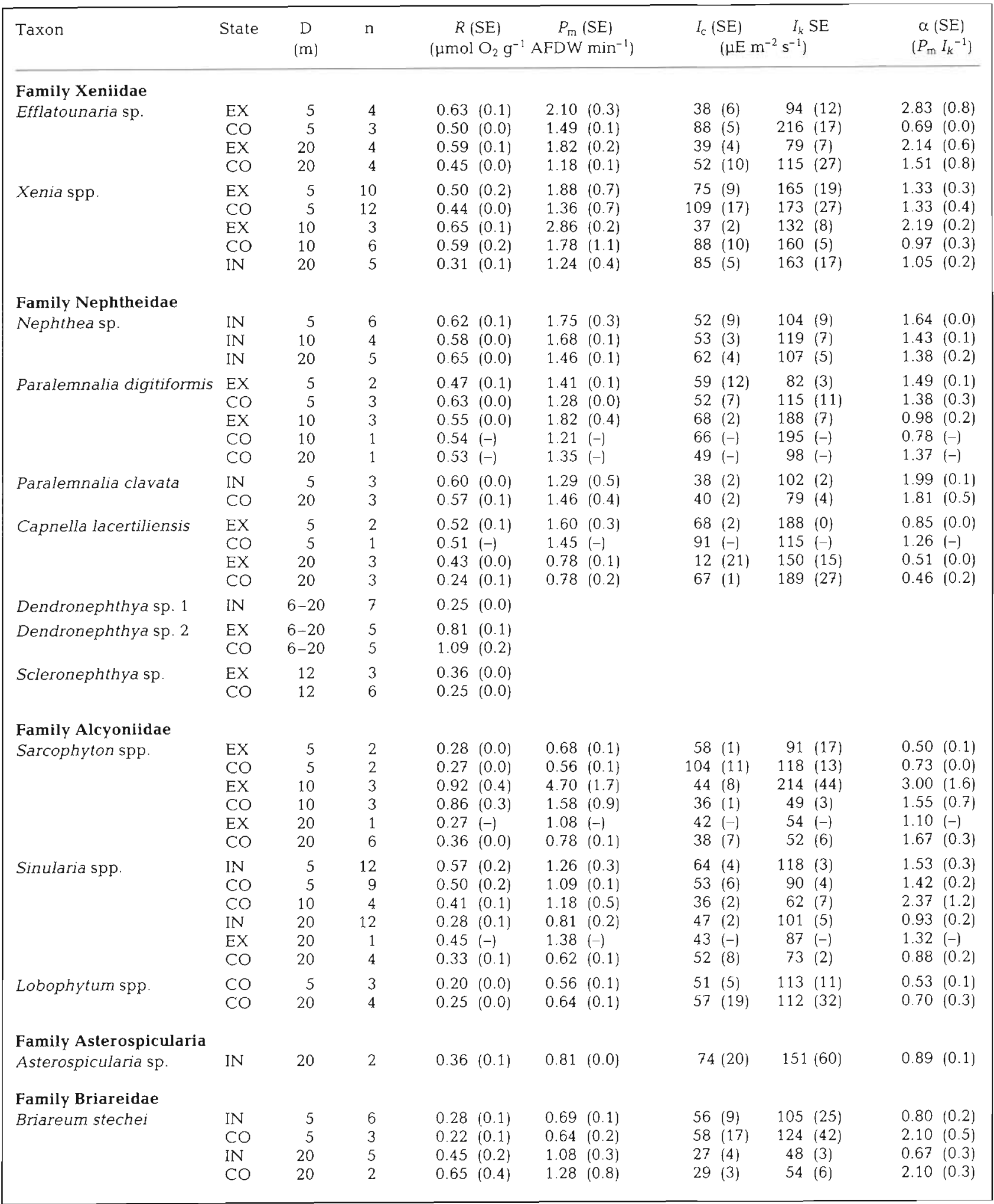




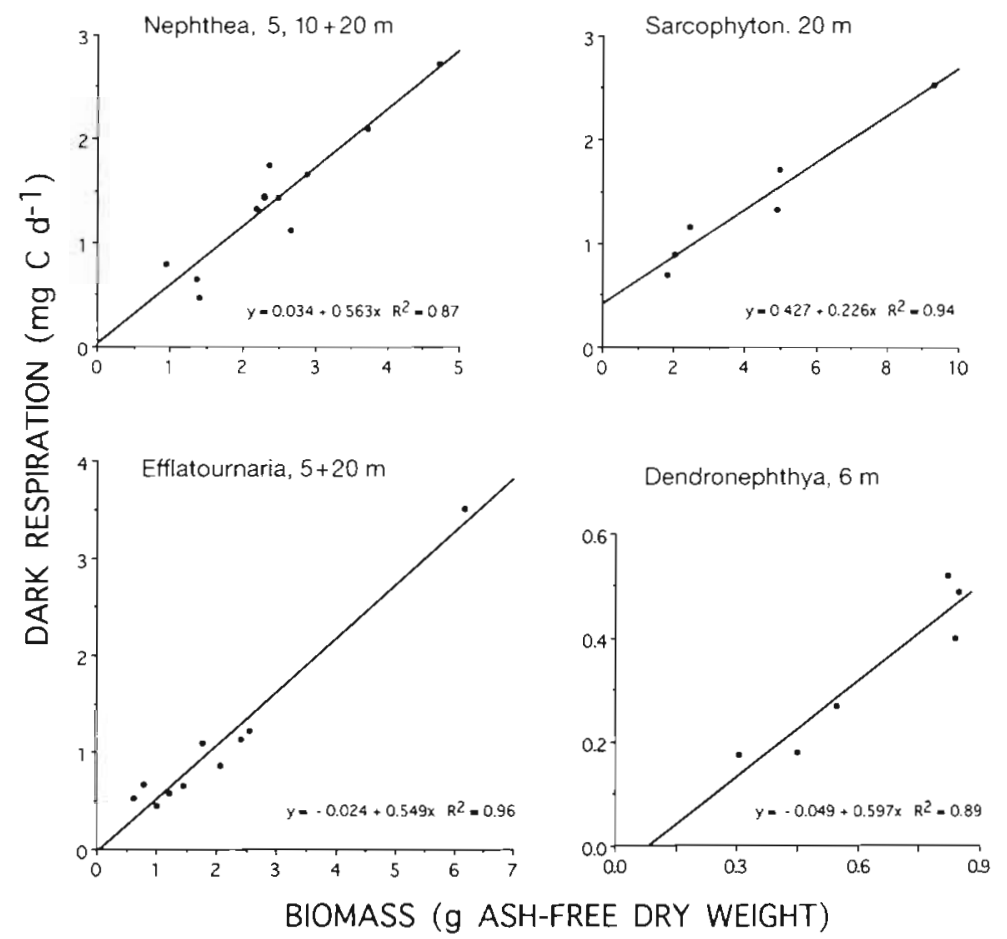

Fig. 1. Dark-respiration rate as a function of colony biomass (AFDW) in 4 soft coral taxa
In general, $I_{C}$ and $I_{k}$ increased when the colonies contracted, showing that greater irradiance was required for the same level of photosynthesis in the contracted state. In only 5 taxa were the numbers of colonies which changed their state during the experiments sufficient to statistically test for the effect of contraction and expansion on coral metabolism (Table 3 ). $P_{\mathrm{g}} / R_{24 \mathrm{~h}}, I_{\mathrm{c}}, I_{k}$ and $\alpha$ differed significantly with state of contraction in those taxa with large polyps (Xenia spp., Efflatounaria sp. and Sarcophyton spp.), but were not significantly affected in Capnella lacertiliensis and Paralemnalia digitiformis, both of which are characterized by very small polyps. The respiratory rates of contracted and expanded specimens of the azooxanthellate taxa Dendronephthya spp. and Scleronephthya sp. did not differ significantly (Wilcoxon paired-sample tests, $p>0.05)$. Respiration rates for contracted zooxanthellate corals were rarely obtained, since these were consistently expanded during the night.
0.2 to $1.1 \mu \mathrm{mol} \mathrm{O}_{2} \mathrm{~g}^{-1}$ AFDW $\mathrm{min}^{-1}$, equivalent to 4.1 to $15.1 \mathrm{mg} \mathrm{C} \mathrm{g}^{-1}$ AFDW d $\mathrm{d}^{-1}$, and were directly proportional to the colonies' AFDW in the range of colony sizes investigated. Fig. 1 displays this relationship for 4 representative taxa, and the correlations were equally linear in the other taxa. There were no obvious effects of depth on rates of respiration. Mean maximum photosynthetic rates were mostly between 0.6 and $2 \mu \mathrm{mol} \mathrm{O}_{2}$ $\mathrm{g}^{-1}$ AFDW $\mathrm{min}^{-1}$. Some Sarcophyton spp. were an exception in having relatively high mean maximum photosynthetic rates of $4.7 \mu \mathrm{mol} \mathrm{O}_{2} \mathrm{~g}^{-1}$ AFDW min ${ }^{-1}$. Photosynthetic compensation irradiance $\left(I_{c}\right)$ ranged between 30 and $120 \mu \mathrm{E} \mathrm{m}^{-2} \mathrm{~s}^{-1}$, and the $50 \%$ saturation irradiance $\left(I_{k}\right)$ was 80 to $180 \mu \mathrm{E} \mathrm{m}^{-2} \mathrm{~s}^{-1}$. The photosynthetic efficiency $\left(\alpha=P_{\mathrm{m}} / I_{k}\right.$ ) showed considerable variation between taxa and depth, and between states of expansion of a colony. Photoinhibition was not evident during these measurements.

In most taxa, colony and polyp expansion and contraction was the main source of the variability in oxygen flux rates (Table 2). For example, Fig. 2 shows the typical effect of contraction and expansion on the $P$-I response curves of a Xenia sp. colony. In colonies with expanded polyps and coenenchyme, $P_{\mathrm{m}}$ and $P_{\mathrm{g}} / R_{24} \mathrm{~h}$ were up to $60 \%$ higher than those in a contracted state. In expanded colonies, $P_{\mathrm{g}} / R_{24} \mathrm{~h}$ was above unity, and averaged $1.30 \pm$ 0.02 (SE) over all taxa, whereas $\mathrm{O}_{2}$ production of contracted colonies was often lower than $\mathrm{O}_{2}$ consumption. Mean $P_{\mathrm{g}} / R_{24 \mathrm{~h}}$ of contracted colonies was $1.14 \pm 0.02$ (SE).

\section{Depth distribution, and depth-dependent primary productivity in soft corals}

The transect analyses revealed a maximum in pooled soft coral abundance at $20 \mathrm{~m}$ depth both on the windward and leeward sides of Davies Reef (mean

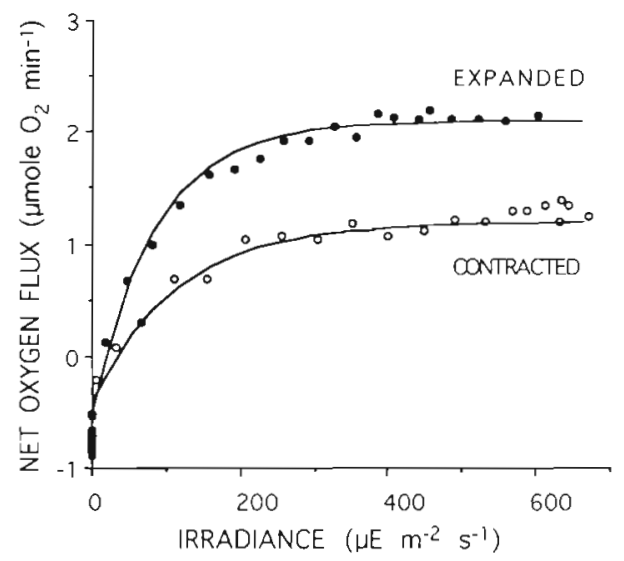

Fig. 2. Xenia sp. Net oxygen flux in a colony in contracted (o) and expanded $(\bullet)$ states. In this example, the $24 \mathrm{~h}$ measurements started at $9.30 \mathrm{~h}$ at an irradiance level of $480 \mu \mathrm{E} \mathrm{m}^{-2} \mathrm{~s}^{-1}$ The coral remained contracted until the evening, expanded at $20.00 \mathrm{~h}$ and stayed expanded until the measurements were concluded the following morning. In expanded state, $P_{\mathrm{m}}=2.1$

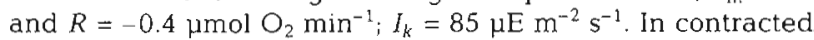
state, $P_{\mathrm{m}}=0.9$ and $R=-0.5 \mu \mathrm{mol} \mathrm{O} \mathrm{min}^{-1} ; I_{k}=115 \mu E \mathrm{~m}^{-2} \mathrm{~s}^{-1}$ Exponential functions were fitted to the curves (solid lines) 
Table 3. Influence of colony contraction on the major photokinetic parameters. Ratio of pairs of measurements on colonies which changed between expanded and contracted state during the experiment, and statistical significance of differences among pairs. $\mathrm{n}$ : number of pairs of measurements. Wilcoxon paired-sample test; $n s: p>0.05$

\begin{tabular}{|c|c|c|c|c|c|c|c|c|c|}
\hline Taxon & $\mathrm{n}$ & $P_{\mathrm{g}} / R_{24 \mathrm{~h}}$ & $\mathrm{p}$ & $I_{c}$ & $\mathrm{p}$ & $I_{k}$ & $\mathrm{p}$ & $\alpha$ & $\mathrm{p}$ \\
\hline Efflatounariasp. & 7 & 1.19 & 0.05 & 0.42 & $<0.02$ & 0.45 & $<0.05$ & 2.79 & 0.02 \\
\hline Xenia spp. & 8 & 1.22 & 0.05 & 0.49 & $<0.02$ & 0.40 & 0.05 & 1.90 & 0.05 \\
\hline Sarcophyton spp. & 7 & 1.61 & $<0.05$ & 0.72 & 0.05 & 4.37 & 0.02 & 0.52 & ns \\
\hline Paralemnalia digitiformis & 6 & 1.07 & ns & 1.13 & ns & 0.71 & ns & 1.09 & ns \\
\hline Capnella lacertiliensis & 6 & 1.17 & ns & 0.96 & ns & 0.99 & ns & 0.88 & ns \\
\hline
\end{tabular}
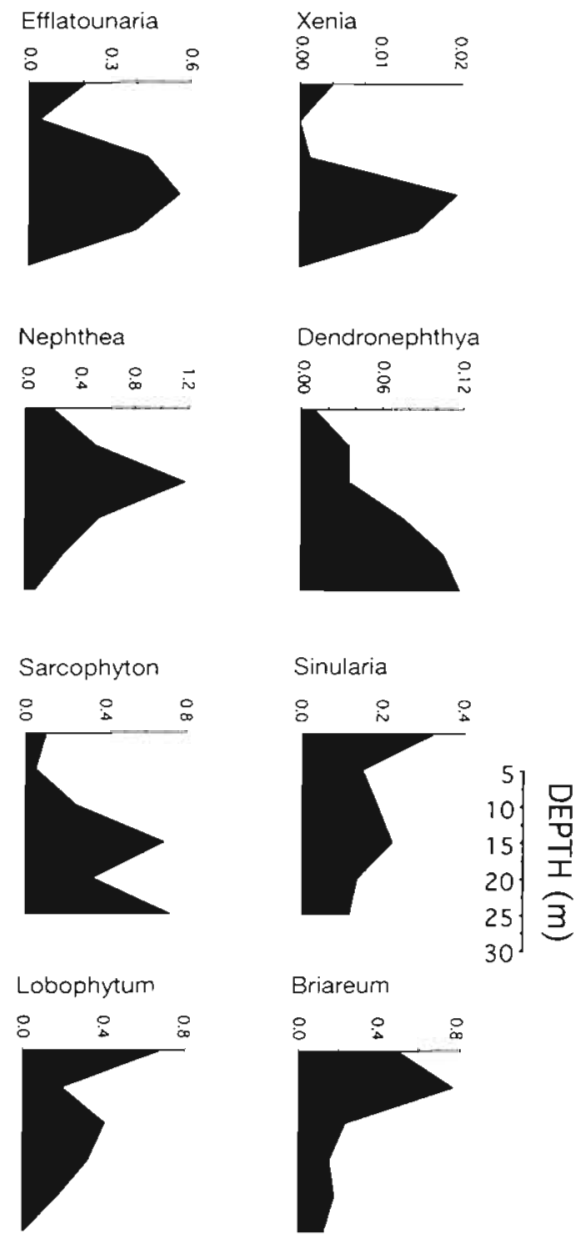

Briareum
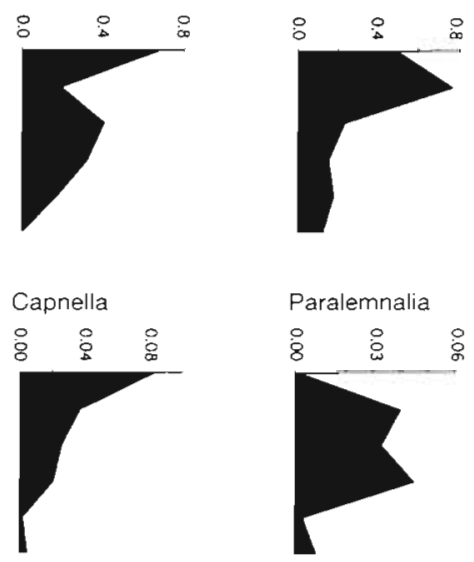

$\%$ COVER

Fig. 3. Depth distribution and density of 10 common soft coral genera on Davies Reef. Data based on 63 transects from all aspects of the outer reef slope, with varying exposure to currents and wave action. Note the different scales on the $y$-axes density over all locations $=16.2 \pm 2.1$ (SE) colonies $\mathrm{m}^{-2}$ ). Total soft coral abundance decreased steadily above and below this depth, to $12.2 \pm 3.7$ and $7.5 \pm$ 3.1 colonies $\mathrm{m}^{-2}$ at 25 and $30 \mathrm{~m}$ depth, respectively, and to a minimum of $5.3 \pm 1.7$ colonies $\mathrm{m}^{-2}$ at $5 \mathrm{~m}$ depth $(2.3 \pm 0.9$ on windward side; $8.2 \pm 3.2$ on leeward side). Mean percentage cover and the bathymetric distribution limits of the 10 most common soft coral genera on the mid-shelf reefs of the central Great Barrier Reef are presented in Fig. 3. Asterospicularia sp. and Scleronephthya spp. are regular components of the soft coral assemblage on many mid- and outer-shelf reefs, but these were rare on Davies Reef, and thus are not included. Massive and encrusting taxa such as Lobophytum spp., Briareum sp. and Sinularia spp. dominated the soft coral communities at $5 \mathrm{~m}$ depth, whereas taller and more gelatinous taxa (most xeniids and nephtheids) were rare in shallow waters, in particular on the windward side of the reef. The lower depth limit for zooxanthellate taxa was commonly around $25 \mathrm{~m}$, but Sarcophyton spp., Sinularia spp. and Briareum sp. were frequently encountered below $30 \mathrm{~m}$. Only the abundance of the azooxanthellate Dendronephthya spp. increased steadily with depth.

PAR was attenuated to $60 \%$ of the surface irradiance at $5 \mathrm{~m}, 16 \%$ at $20 \mathrm{~m}$, and $11 \%$ at $30 \mathrm{~m}$ depth (Fig. $4 \mathrm{a}$ ). Differences in PAR attenuation between windward and leeward sides of the reef were small on the 3 days of measurement. The gross and net photosynthetic productivity at 5 and $20 \mathrm{~m}$, and the period of photosynthetic compensation during a summer's day at the deepest depth of occurrence were calculated for the 10 zooxanthellate soft coral taxa (Table 4). The calculations were based on the $24 \mathrm{~h}$ cycle of irradiance at given depths (Fig. $4 \mathrm{~b}$ ), and the measured $P$ - $I$ parameters of each of the taxa (Table 2). In shallow waters (5 m) mean $P_{\mathrm{g}}$ pooled over all taxa was $8.3 \pm 1.1$ (SE) $\mathrm{mg}$ $\mathrm{C} \mathrm{g}^{-1}$ AFDW d $\mathrm{d}^{-1}$, and $P_{\mathrm{n}}$ was mostly low, but positive (pooled mean $=2.1 \pm 0.7 \mathrm{SE} \mathrm{mg} \mathrm{C} \mathrm{g}{ }^{-1}$ AFDW d ${ }^{-1}$ ). Efflatounaria sp. and Nephthea sp. had the highest $P_{g}$ in shallow waters. At $20 \mathrm{~m}$ depth, mean $P_{g}(5.5 \pm 0.6 \mathrm{mg} \mathrm{C}$ $\mathrm{g}^{-1}$ AFDW d $\mathrm{d}^{-1}$ ) was on average $34 \%$ lower than that 

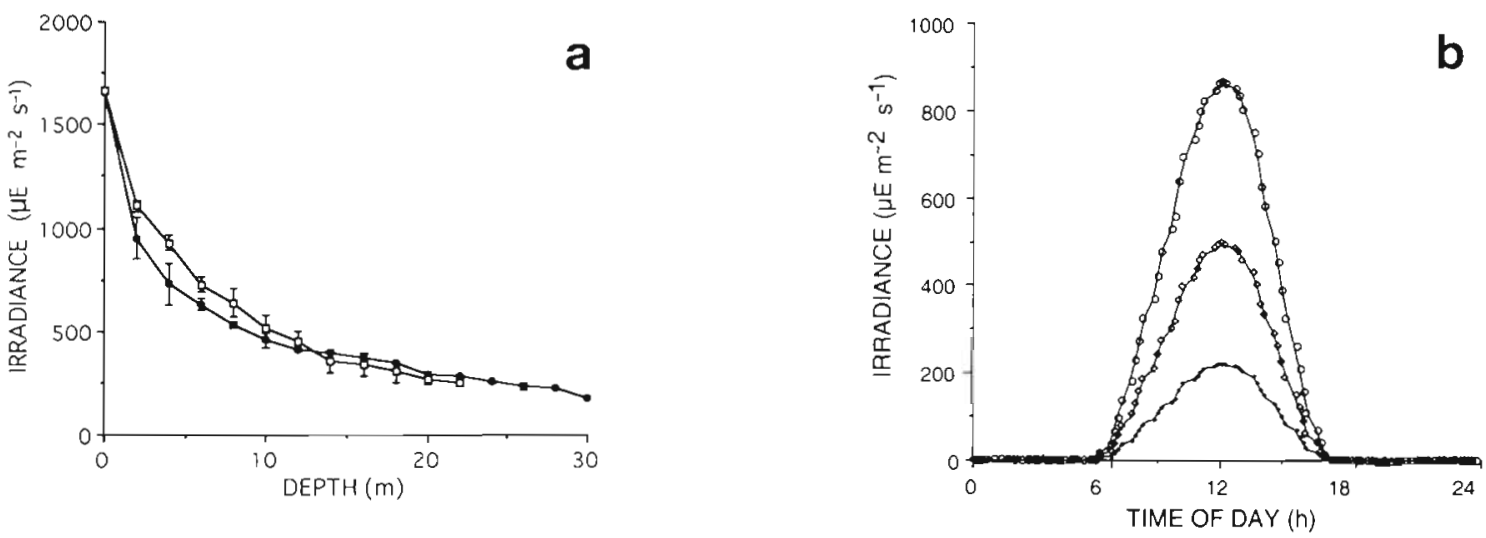

Fig. 4. (a) Variation in PAR transmission with depth at different locations on Davies Reef. Measurements were performed at noon on 3 consecutive cloudless days in early summer. Bars: standard deviations; ( ) windward side of reef $(n=3)$; $(\square)$ leeward side $(n=3)$. (b) Change in solar irradiance with time and water depth on a cloudless summer day on Davies Reef. Measurements were taken at $5 \mathrm{~m}$ and extrapolated to 10 and $20 \mathrm{~m}$ using the data of PAR transmission $(60 \%$ of surface irradiance at $5 \mathrm{~m}, 36 \%$ at $10 \mathrm{~m}$ and $16 \%$ at $20 \mathrm{~m}$ )

in shallow waters. Respiration rates did not change significantly with depth. In all taxa, photosynthetic productivity at $20 \mathrm{~m}$ depth was insufficient to balance respiration, with the exception of Efflatounaria sp. and expanded forms of Sarcophyton spp. and Sinularia spp. Net productivity at $20 \mathrm{~m}$ averaged $-0.8 \pm 0.5 \mathrm{mg} \mathrm{C}$ $\mathrm{g}^{-1}$ AFDW d ${ }^{-1}$.

The ability of soft corals to compensate for lower light levels with higher photosynthetic efficiency varied between taxa. Capnella lacertiliensis, Nephthea sp., Lobophytum spp. and Xenia spp. never reached saturation at $20 \mathrm{~m}$ depth, and Efflatounaria sp. and Paralemnalia spp. were light saturated only briefly in summer at such depths. Briareum stechei showed the strongest capacity for photo-adaptation, with significantly reduced $I_{c}$ and $I_{k}$, and increased $\alpha$ values in colonies from $20 \mathrm{~m}$ depth compared with those from 5 $m$ depth (2-tailed Mann-Whitney test, $\mathrm{p} \leq 0.05$ for each

Table 4. Gross and net photosynthetic productivity for soft corals in expanded (EX) and contracted (CO) state, at 5 and $20 \mathrm{~m}$ depth, during cloudless summer days (November) on Davies Reef. Depth distribution at Davies Reef are given for the same taxa. Daily period of photosynthetic compensation, calculated for deepest depth of occurrence (30 m for Sarcophyton spp., Sinularia spp. and Briareum stecheil at summer irradiance

\begin{tabular}{|c|c|c|c|c|c|c|c|}
\hline Taxon & $\begin{array}{c}\text { Depth } \\
\text { distribution } \\
\text { (m) }\end{array}$ & State & $\begin{array}{c}\text { Period of } \\
\text { compensation } \\
\text { (h, min) }\end{array}$ & $\underset{5 \mathrm{~m}}{(\mathrm{mg} \mathrm{Cg}}$ & $\begin{array}{l}P_{\mathrm{g}} \\
\stackrel{\left.\mathrm{AFDW} \mathrm{d}^{-1}\right)}{20 \mathrm{~m}}\end{array}$ & $\underset{5 \mathrm{~m}}{(\mathrm{mg} \mathrm{C} \mathrm{g}}$ & $\begin{array}{l}P_{\mathrm{n}} \\
{ }^{\left.\mathrm{AFDW} \mathrm{d} \mathrm{d}^{-1}\right)} \\
\quad 20 \mathrm{~m}\end{array}$ \\
\hline Efflatournaria sp. & $2-25$ & $\begin{array}{l}\text { EX } \\
\text { CO }\end{array}$ & $\begin{array}{l}5.30 \\
4.50\end{array}$ & $\begin{array}{r}15.6 \\
9.3\end{array}$ & $\begin{array}{l}9.0 \\
6.7\end{array}$ & $\begin{array}{l}6.9 \\
2.4\end{array}$ & $\begin{array}{l}0.9 \\
0.4\end{array}$ \\
\hline Xenia spp. & $5-25$ & $\begin{array}{l}E X \\
C O\end{array}$ & $\begin{array}{r}- \\
4.0\end{array}$ & 9.2 & 6.7 & 3.2 & -2.4 \\
\hline Nephthea sp. & $3-25$ & $\begin{array}{l}\text { EX } \\
\text { CO }\end{array}$ & $\begin{array}{c}- \\
4.40\end{array}$ & $\begin{array}{r}15.3 \\
8.2\end{array}$ & 7.5 & $\begin{array}{r}4.3 \\
-2.7\end{array}$ & -1.5 \\
\hline Paralemnalia spp. & $2-20$ & $\mathrm{CO}$ & 5.30 & 9.3 & 8.2 & 1.7 & -0.3 \\
\hline Capnella lacertiliensis & $2-20$ & $\begin{array}{l}\text { EX } \\
\text { CO }\end{array}$ & $\begin{array}{l}6.00 \\
4.15\end{array}$ & 10.7 & $\begin{array}{l}3.2 \\
2.8\end{array}$ & 4.9 & $\begin{array}{l}-0.5 \\
-2.7\end{array}$ \\
\hline Sarcophyton spp. & $0->30$ & $\begin{array}{l}\text { EX } \\
\text { CO }\end{array}$ & $\begin{array}{l}3.25 \\
3.20\end{array}$ & $\begin{array}{l}5.0 \\
4.0\end{array}$ & $\begin{array}{l}6.8 \\
5.0\end{array}$ & $\begin{array}{l}1.2 \\
0.2\end{array}$ & $\begin{array}{r}3.1 \\
-0.1\end{array}$ \\
\hline Sinularia spp. & $0->30$ & $\begin{array}{l}E X \\
C O\end{array}$ & $\begin{array}{l}3.20 \\
3.05\end{array}$ & $\begin{array}{l}8.1 \\
5.1\end{array}$ & $\begin{array}{l}7.5 \\
3.6\end{array}$ & $\begin{array}{l}1.1 \\
0.7\end{array}$ & $\begin{array}{r}1.2 \\
-1.1\end{array}$ \\
\hline Lobophytum spp. & $0-25$ & $\mathrm{CO}$ & 4.45 & 4.0 & 3.1 & 1.3 & -0.3 \\
\hline Asterospicularia sp. & $?$ & IN & ? & & 2.7 & & -1.5 \\
\hline Briareum stechei & $5^{a}->30$ & $\mathrm{CO}$ & 3.30 & 4.5 & 3.6 & 1.5 & -0.9 \\
\hline Average & & & & 8.3 & 5.5 & 2.1 & -0.8 \\
\hline On vertical surfaces & & & & & & & \\
\hline
\end{tabular}


factor). Differences in $P_{\mathrm{q}} / R_{24} \mathrm{~h}$ and $R$ between specimens from 5 and $20 \mathrm{~m}$ were not significant $(p>0.1)$.

The lower depth distribution limits of the 10 zooxanthellate soft corals at Davies Reef, and the calculated rates of primary productivity appeared to be partly related (Table 4). At their lower depth limits, these taxa experienced 3 to $5.5 \mathrm{~h} \mathrm{~d}^{-1}$ of photosynthetic compensation, but light was insufficient for photosynthetic saturation. The distribution of Sinularia spp., Sarcophyton spp. and Briareum stechei, unlike the other taxa examined, extended to depths below $30 \mathrm{~m}$ at Davies Reef These taxa were photosynthetically saturated at $20 \mathrm{~m}$ for 3.5 to $5 \mathrm{~h} \mathrm{~d}^{-1}$, and gross photosynthetic production in Sinularia spp. and Sarcophyton spp. still exceeded respiration when in the expanded state $\left(P_{n}>0\right)$. The same was true for Efflatounaria spp. which had highest cover of all taxa at 20 to $25 \mathrm{~m}$ depth, but which did not occur below $25 \mathrm{~m}$. In the remaining genera, which were rarely encountered below 20 or $25 \mathrm{~m}$ at Davies Reef, respiration exceeded gross productivity at $20 \mathrm{~m}$ depth, i.e. $P_{\mathrm{n}}<0$.

\section{DISCUSSION}

All 10 zooxanthellate soft coral genera of mid-shelf reefs on the Great Barrier Reef have low rates of primary productivity, and appear to depend both on phototrophy and heterotrophy to supply their carbon requirements. These soft corals mostly occur in greatest abundance (percent cover and colony numbers) at around $20 \mathrm{~m}$ depth, but in all except 2 of the investigated taxa phototrophic carbon uptake was insufficient to cover respiratory carbon demand. Even colonies living in shallow water fixed photosynthetic carbon at a rate barely above the rate of carbon consumption. These estimates of the relative contribution of phototrophy to soft coral nutrition are probably overestimated for the following reasons. Rates of primary production in soft corals were simulated using optimal light conditions (cloudless, calm days), and these are probably lower under natural conditions. Furthermore, this and other studies have assessed the nutritional role of phototrophy in soft corals in relation to respiratory carbon requirements only. Requirements for somatic growth, reproduction and mucus production must also be taken into account for a complete assessment of the roles of phototrophy and heterotrophy in soft corals. Very few data exist which quantify these costs in soft corals, but measurements on hard corals show that they can be significant. For example, the amount of carbon invested into growth is equal to $24-59 \%$ of the respiratory demand in the stony coral Porites porites (Edmunds \& Davies 1989), and Szmant (1991) found 15 to $45 \%$ of respiratory demand invested into gonad development in the stony coral Monastrea annularis. Given the presented data on primary production and respiration and the above qualifications, we conclude that these soft corals are probably mixotrophic across their depth range.

There are many contradictions in the various studies on metabolism and nutrition in octocorals. Our results agree closely with those of Mergner \& Svoboda (1977) who recorded $P_{\mathrm{g}} / R_{24} \mathrm{~h}$ of 1.0 to 1.2 in 4 soft coral species from the Red Sea (Litophyton, Xenia, and 2 Heteroxenia species). In the present study, $P_{\mathrm{m}} / R$ ratios were 2.3 to 5.3 . Sorokin (1991) reported $P_{\mathrm{m}} / R$ ratios of 0.7 to 2.7 for a series of soft corals from the Great Barrier Reef, measured in 'ambient sunlight' over 2 to $3 \mathrm{~h}$ incubations. However, in that study, the respirometer containers were not stirred, and no information was given on sampling depth, irradiance levels during the experiments, number of replicate colonies and variability between and among individuals. Xenia and Heteroxenia have been classified as completely autotrophic, and unable to take up particulate food (Gohar 1940, Schlichter et al. 1983), but Lewis (1982) found a number of prey items in the gastrovascular cavities of Xenia. Our data support the view that the Xenia is indeed dependent on both heterotrophy and phototrophy. Lewis (1982) and Sorokin (1991) stated that Sarcophyton was the most efficient predator of all taxa, and seemed able to completely satisfy respiratory losses by heterotrophic feeding. Sarcophyton is one of the highest primary producers in the present study, in particular in deep-water adapted colonies, and may be nutritionally one of the most flexible soft coral genera.

Ratios of primary productivity to respiration in soft corals are lower than those of hard corals and other zooxanthellate reef invertebrates. $P_{\mathrm{g}} / R_{24} \mathrm{~h}$ values in the investigated soft corals averaged $1.3 \pm 0.02$ (SE) in expanded, and $1.14 \pm 0.02$ in contracted colonies. Highest $P_{\mathrm{g}} / R_{24} \mathrm{~h}$ values were found in Sarcophyton spp. $\left(P_{\mathrm{g}} / R_{24 \mathrm{~h}}=1.8\right)$ and Paralemnalia spp. and Nephthea sp. $\left(P_{\mathrm{g}} / R_{24 \mathrm{~h}}=1.7\right)$ when in the expanded state at $6 \mathrm{~m}$ depth. In comparison, obligate phototrophic coral reef sponges have much higher ratios (mean $P_{\mathrm{g}} / R_{24 \mathrm{~h}}=3.6$ ), except for Strepsichordaia lendenfeldi $\left(P_{\mathrm{g}} / R_{24 \mathrm{~h}}=1.2\right)$, the only sponge classified as a mixotroph (Cheshire \& Wilkinson 1991). Generally, $P_{\mathrm{g}} / R_{24} \mathrm{~h}$ ratios in hard corals range between 2 and 4 (Muscatine et al. 1981, Chalker et al. 1985), despite their relatively high respiration rates. Thus hard corals have much higher photosynthetic rates than soft corals. It is now accepted that most hard corals are able to derive all of their respiratory carbon requirements from their symbiotic algae (e.g. Falkowski et al. 1984, Muscatine et al. 1984). All these listed $P_{\mathrm{g}} / R_{24 \mathrm{~h}}$ ratios reflect oxygen rather than carbon ratios. Thus in order to accurately quantify the phototrophic contribution to the colonies' energy 
supply, these data need to be qualified by $P Q, R Q$ and carbon translocation rates from symbiotic algae to host, and PAR exposure in the natural habitat.

Respiration rates in octocorals are low in comparison to those of stony corals. Our measurements of respiration in soft corals ( 3 to $13 \mathrm{mg} \mathrm{C} \mathrm{g}^{-1}$ AFDW d ${ }^{-1}$ ) are similar to those found in 5 Caribbean gorgonian species (1.2 to $6.16 \mathrm{mg} \mathrm{C} \mathrm{g}^{-1}$ organic matter $\mathrm{d}^{-1}$; Lewis \& Post 1982). By comparison, respiration rates in hard corals are up to an order of magnitude higher. For example, the respiration rates of 7 shallow-water hard corals from the Caribbean ranged between 40 and $203 \mathrm{mg} \mathrm{C}$ $\mathrm{g}^{-1}$ AFDW d $\mathrm{d}^{-1}$ (Davies 1980; note that a dry-weight/ AFDW conversion factor of 4 was applied to his data), and between 65 and $134 \mathrm{mg} \mathrm{C} \mathrm{g}^{-1}$ AFDW $\mathrm{d}^{-1}$ in the stony coral Pocillopora damicornis (Jokiel \& Morrissey 1986).

The reason for the comparatively low metabolic rates (photosynthesis and respiration) in soft corals is not precisely known. However, the ratio of body surface area to volume, which determines both gas exchange through the epidermal tissue and PAR exposure, is low in soft corals (fleshy and massive colony shapes) compared with hard corals (thin layers of tissue spread over the exoskeleton). The contribution of a low surface area to volume ratio to low photosynthetic activity is indicated by the enhancement in soft coral of primary production during expansion. Expansion of coenenchyme and polyps considerably enlarges the total area of photosynthetically active tissue, and increases the ratio of body surface area to volume. Farrant et al. (1987) found a 300\% increase in surface area of Capnella gaboensis due to coenenchyme expansion, and the increase in surface area due to polyp expansion would presumably add to this. The greatest proportion of zooxanthellae are located in the polyps of many alcyoniid and xeniid taxa (Fabricius unpubl. data), thus contraction or retraction of the polyps removes the zooxanthellae from the surface, with the result that higher irradiance is required to reach the algae. Accordingly, we have shown that $I_{c}$ and $I_{k}$ are generally higher in contracted than in expanded colonies of soft corals that have large retractable polyps. Colony growth form and polyp size in the soft coral taxa considered here were, however, unrelated to rates of photosynthetic productivity.

Little has been published on soft coral behavioral aspects such as colony and polyp contraction and expansion. In shallow mid-shelf areas of the Great Barrier Reef, the proportion of colonies which are diurnally expanded was found to be highly variable in most taxa, whereas the great majority of taxa were predictably expanded at night. In the Red Sea, the same genera were also commonly found contracted during the night. Environmental factors such as irradi- ance and water flow seemed to trigger contraction in some but not all taxa. For example, the Red Sea species Xenia obscuronata contracted diumally on horizontal surfaces in times of high irradiance, but the same species remained expanded on vertical, shaded sites. Other Xenia species were almost continuously expanded during the day, but commonly contracted at night. Dendronephthya hemprichi in the Red Sea contracted diurnally at water flow rates of less than 4 and greater than $25 \mathrm{~cm} \mathrm{~s}^{-1}$, but was expanded in intermediate flow, and under all flow conditions at night (all Fabricius unpubl. data).

Polyp contraction or expansion during the day may permit zooxanthellate soft corals to continuously finetune their carbon to nitrogen balance. Expansion leads to increased photosynthetic carbon production, however, it has been suggested by Sebens \& DeRiemer (1977) that it also enhances the loss of nitrogen and nutrients through the epidermal tissue. Our measurements on 10 zooxanthellate soft corals have shown that the photosynthetic activity is too low to produce any significant carbon surplus. Thus, at times when the potential for uptake of particulate food is low (e.g. at conditions of low water flow rates), there may exist a trade-off between carbon gain and nutrient loss which varies depending on the state of expansion.

There is some indication that irradiance and wave action together limit the bathymetric distribution of the investigated soft coral taxa on Davies Reef. The lowest depths of occurrence of each taxa approximate the depth at which these cease to reach photosynthetic saturation. This suggests that irradiance is a factor determining the lower distribution limit in zooxanthellate soft coral taxa. Dinesen (1983) suggested that the upper depth limit to soft coral distribution may be related to the damaging effect of wave action. This is supported by our observation that densities of the more delicate capitate and arborescent taxa (e.g. Xenia spp. and Nephthea spp.) in shallow waters were 2- to 3-fold higher on leeward than on windward sides of reefs. These taxa occur on sheltered sides of reefs, but are absent, except in crevices, in the 5 to $10 \mathrm{~m}$ zone of exposed regions. In contrast, the encrusting taxa (Lobophytum spp., Sinularia spp. and Briareum sp.), which are least subject to drag forces and thus are most resistant to wave stress, grow in shallow waters along the windward side of Davies Reef. The more sheltered inshore reefs of the central Great Barrier Reef possess the highest soft coral densities at 1 to $3 \mathrm{~m}$ depth, even in the intertidal zone (Dinesen 1983).

Thus the lack of a solid, supporting skeleton seems to limit many soft coral taxa to depths where there is little wave action, but where irradiance is strongly attenuated. This lack of a central skeleton also results in a low ratio of photosynthetic surface area relative to body 
volume, and consequently a low rate of photosynthetic productivity. Given these characteristics, a mixed phototrophic and heterotrophic nutrition is required for zooxanthellate soft corals to inhabit the zone between damaging wave stress in the shallows and the dark depths.

Acknowledgements. Many thanks to David Mckinnon for technical assistance in maintaining the respirometers in the field, and for many hours of diving assistance. John Small and John Collingwood gave technical support with the respirometers. Phil Alderslade, Museum of Northern Territories, helped confirm taxonomic identifications of the soft corals. Ed Drew and D. Schlichter provided helpful comments on a draft of the manuscript. K.F. acknowledges the support of a PhD fellowship of the University of Munich, and of an AIMS Postgraduate Scholarship. This is AIMS Contribution No. 698.

\section{LITERATURE CITED}

Chalker BE, Carr K, Gill E (1985) Measurement of primary production and calcification in situ on coral reefs using electrode techniques. Proc 5th int Coral Reef Symp 6: $167-171$

Chalker BE, Dunlap WC, Oliver JK (1983) Bathymetric adaptations of reef-building corals at Davies Reef, Great Barrier Reef, Australia. Il. Light saturation curves for photosynthesis and respiration. J exp mar Biol Ecol 73:37-56

Cheshire AC, Wilkinson CR (1991) Modelling the photosynthetic production by sponges on Davies Reef, Great Barrier Reef. Mar Biol 109:13-18

Davies PS (1980) Respiration in some Atlantic reef corals in relation to vertical distribution and growth form. Biol Bull 158:187-194

Dinesen ZD (1983) Patterns in the distribution of soft corals across the central Great Barrier Reef. Coral Reefs 1 229-236

Edmunds PJ, Davies PS (1988) Post-illumination stimulation of respiration rate in the coral Porites porites. Coral Reefs $7: 7-9$

Edmunds PJ, Davies PS (1989) An energy budget for Porites porites (Scleractinia), growing in a stressed environment. Coral Reefs 8:37-43

Fabricius KE (in press) Soft coral abundances on the central Great Barrier Reef: an analysis of changes after Acanthaster outbreaks, and of some environmental controls. Coral Reefs

Fabricius KE, Benayahu Y, Genin A (1995) Herbivory in asymbiotic soft corals. Science 268:90-92

Fabricius KE, Genin A, Benayahu $Y$ (in press) Flowdependent herbivory and growth in asymbiotic soft corals. Limnol Oceanogr

Falkowski PG, Dubinsky Z, Muscatine L, Porter JW (1984) Light and the bioenergetics of a symbiotic coral. BioSci 34 : $705-709$

This article was submitted to the editor
Farrant PA, Borowitzka MA, Hinde R, King RJ (1987) Nutrition of the temperate soft coral Capnella gaboensis. II. The role of zooxanthellae and feeding. Mar Biol 95:575-581

Gohar HAF (1940) Studies on the Xeniidae of the Red Sea. Publs mar biol Stn Ghardaqa 2:25-118

Hatcher A (1989) RQ of benthic marine invertebrates. Mar Biol 102:445-452

Jokiel PL, Morrissey JI (1986) Influence of size on primary production in the reef coral Pocillopora damicomis and the macroalga Acanthophora spicifera. Mar Biol 91:15-26

Klumpp DW, McKinnon DA, Daniel P (1987) Damselfish territories: zones of high productivity on coral reefs. Mar Ecol Prog Ser 40:41-51

Lewis JB (1982) Feeding behaviour and feeding ecology of the Octocorallia (Coelenterata: Anthozoa). J Zool, Lond 196:371-384

Lewis JB, Post EE (1982) Respiration and energetics in West Indian Gorgonacea (Anthozoa, Octocorallia). Comp Biochem Physiol 71A:457-459

Mariscal RN, Bigger CH (1977) Possible ecological significance of octocoral epithelial ultrastructure. Proc 3rd int Coral Reef Symp 1:128-133

Mergner H, Svoboda A (1977) Productivity and seasonal changes in selected reef areas in the Gulf of Aqaba (Red Sea). Helgoländer wiss Meeresunters 30:383-399

Muller-Parker G (1984) Photosynthesis-irradiance responses and photosynthetic periodicity in the sea anemone Aiptasia pulchella and its zooxanthellae. Mar Biol 82:225-232

Muscatine L, Falkowsky P, Porter JW, Dubinsky Z (1984) Fate of photosynthetically fixed carbon in light and shade adapted colonies of Stylophora pistillata. Proc R Soc Lond 222:181-202

Muscatine L, McCloskey LR, Marian RE (1981) Estimating the daily contribution of carbon from zooxanthellae to coral animal respiration. Limnol Oceanogr 26:601-611

Nelson SG, Siegrist AW (1987) Comparison of mathematical expressions describing light-saturation curves for photosynthesis by tropical marine macroalgae. Bull mar Sci 41 : $617-622$

Schlichter D (1982) Nutritional strategies in cnidarians: the absorption, translocation and utilization of dissolved nutrients by Heteroxenia fuscescens. Am Zool 22:659-669

Schlichter D, Svoboda A, Kremer BP (1983) Functional autotrophy of Heteroxenia fuscsescens (Anthozoa: Alcyonaria): carbon assimilation and translocation of photosynthates from symbionts to host. Mar Biol 78:29-38

Sebens KP, DeRiemer K (1977) Diel cycles of expansion and contraction in coral reef anthozoans. Mar Biol 43:247-256

Shick JM, Brown WI, Dolliver EG, Kayar SR (1979) Oxygen uptake in sea anemones: effects of expansion, contraction, and exposure to air and the limitations of diffusion. Physiol Zool 52:50-62

Sorokin YI (1991) Biomass, metabolic rates and feeding of some common reef zoantharians and octocorals. Aust J mar Freshwat Res 42:729-741

Szmant AM (1991) Sexual reproduction by the Carribean reef corals Monastrea annularis and $M$. cavernosa. Mar Ecol Prog Ser 74:13-25

Manuscript first received: July 5, 1994

Revised version accepted: March 30, 1995 